\title{
СИНОНИМИЧЕСКИЕ СООТВЕТСТВИЯ В ТЕМАТИЧЕСКОЙ ГРУППЕ «НАЗВАНИЯ ПИЩИ» (НА ПРИМЕРЕ ВОРОНЕЖСКИХ ГОВОРОВ)
}

\author{
Synonymous Matches in the "Food Names" Topic Group \\ (on the Example of Voronezh Dialects)
}

Keywords: synonymous matches, food names, nomination principles, vocabulary, Voronezh dialects

Contact: ВГУ; Darij98@yandex.ru

Одним из самых древних компонентов материальной культуры всех народов является пища. Она отличается устойчивостью и традиционностью, несмотря на определенные изменения во времени под влиянием различных факторов. Комплекс основных блюд дает представление о том, какие продукты растительного и животного происхождения окружали представителей того или иного народа в древности. Кроме того, способы приготовления и употребления пищи отражают старинные обычаи и исконное мировоззрение людей.

На русской территории особенности пищи были рассмотрены в трудах историков и этнографов Т.А. Ворониной, С.А. Арутюнова, В.В. Похлебкина, В.К. Соколовой, Л.Н. Чижиковой, М.Н. Шмелевой и др. На территории Воронежской области о блюдах и связанных с ними обрядах частично писали П. Малыхин, Д. Зеленин, А. Путинцев. С лингвистической точки зрения пища Воронежского края анализировалась в статьях И.К. Зайцевой (1977), а также в масштабном диссертационном исследовании Т.В. Карасевой (2004).

В нашей работе мы обратились к тому аспекту, который ранее не был рассмотрен на материале данной тематической группы воронежских говоров: синонимические соответствия и особенности их функционирования. Отметим, что «слова, обозначающие одну и ту же реалию и принадлежащие разным говорам, образуют ряд синонимических соответствий (параллелей)» (Блинова 1975: 168). Исследование лексики определенной тематической группы через призму синонимических соответствий способствует созданию более полной 
и систематизированной картины лексического состава какой-либо диалектной макросистемы.

В рамках нашего исследования был собран пласт лексики воронежских говоров, относящийся к названиям пищи; проведена систематизация выявленных лексем; построены синонимические ряды; обозначены принципы номинации синонимических соответствий; рассмотрены словообразовательные процессы.

Материалом нашего исследования послужили: 1. картотека «Словаря воронежских говоров»; 2. «Словарь воронежских говоров», вып. 1-3, 2004, 2007 , 2019 гг.; 3. персональная картотека автора.

В построенных рядах синонимических соответствий четко прослеживаются два основных источника возникновения диалектной синонимии: 1. различные принципы номинации вследствие неодинакового восприятия мира коллективом диалектоносителей; 2. словообразовательные процессы. Рассмотрим указанные источники на конкретных примерах.

Примером синонимического ряда, состоящего из лексем с различными принципами номинации, может служить ряд со значением 'картофельное пюре': бухо'ня - ду'тики - карто'шка мя'тая - карто'шная ка'ша - карто'шник-мя'тка - мяту'ха - толкани'цуа - толкано'к - толченка - топту'н. В данном ряду выделяются следующие номинации:

1. По основному продукту: карто'иник.

2. По способу приготовления:

- с мотивирующей основой мя-: мя'тка, мяту'ха;

- с мотивирующей основой топm-: топту'н;

- с корнем -толк- (-толч-): толкани'и̧а, толкано'к, толченка.

3. По консистенции:

- с мотивирующей основой бухон-: бухо'ня. Связано с мягкостью приготовляемого блюда. В русских говорах бухо'нить 'делать что-либо мягким, пышным’ (Курск.), бухо'нный ‘пышный, мягкий’ (Новг.), бухо'ный 'пышный, хорошо испеченный' (Волог., Яросл., Новг.Север., Твер., Курск) (СРНГ 1968: 324).

- с мотивирующей основой $\partial y m-:$ ду'тики. Связано с мягкостью, воздушностью, «дутостью» блюда. У В.И. Даля дутик 'раздутая вещь, пузырь', а также 'человек полный в лице или вообще плотный коротыш, толстячок' (Даль 1935: 518). В русских говорах бытует лексема $\partial y^{\prime} т н и к$ 
в значении 'пресная ржаная лепешка, облитая сверху раствором гороховой муки' (СРНГ 1972: 274).

В названиях, которые представляют собой словосочетания, соединяются два способа номинации: по основному продукту и способу приготовления: карто'шка мя'тая; по основному продукту и консистенции: карто'шная ка'ша.

Таким образом, в ряду синонимических соответствий со значением 'картофельное пюре' в воронежских говорах самым распространенным принципом номинации является способ приготовления (картофель мнут, толкут, mопчуm - это является определяющим признаком данного блюда).

Проанализировав все выявленные синонимические соответствия в тематической группе «Названия пищи», мы выделили самые частотные принципы номинации (приводятся фрагменты синонимических рядов):

1. Номинации по способу приготовления: дра'нки - дра'нчики - каварду'шки 'картофельные оладьи'. Происхождение слов дра'нки, дра'нчики связано с диалектным глаголом драть в значении 'измельчать, дробить', ‘тереть на терке (картофель)' (смоленское) (СРНГ 1972: 175). Слово кавардушки связано с глаголами кавардать, кавырдать, которые в воронежских говорах имеют значение 'ворочить, переворачивать', т.е. оладьи в процессе жарки переворачивают на сковороде, кавардают.

2. Номинации по основному продукту: костри'чник - крапи'вник - суп с жи'гой 'суп из крапивы'. Отметим, что костри'ка и жи'га - это названия крапивы в воронежских говорах.

3. Номинации по консистенции: дрожа'чка - дры'га - дря'зга'ло 'холодец'.

4. Номинации по форме: кола'бух - ко'лоб - кругля'к 'круглый хлеб; каравай'. Слова колабух и колоб восходят к древнерусскому коло 'круг' (Черных 1999: 411).

5. Номинации по вкусу: солоду'ха - солоду'шки 'свекольный суп'. Известно, что солод и продукты из солода имеют приятный, сладкий вкус.

Необходимо ответить, что самыми многочисленными рядами синонимических соответствий являются ряды, в которых представлены лексемы со значением: 'оладьи' - 14 синонимических соответствий, 'картофельные оладьи' - 12; ‘картофельное пюре' - 11; ‘холодец' - 10; ‘круглый хлеб; каравай’ - 7, 'картофель, сваренный в кожуре' - 7. 
Из приведенных рядов видно, что наибольшее количество синонимических соответствий называет блюда из картофеля (картофельные оладьи; картофель пюре; картофель, сваренный в кожуре), холодец, а также хлебобулочные изделия (оладьи, каравай). Следовательно, можно сделать вывод, что названные блюда являются одними из самых распространенными среди воронежских диалектоносителей.

Нельзя не отметить связь синонимии с многозначностью. Некоторые выявленные лексемы являются многозначными, т.е. входят в различные ряды синонимических соответствий данной тематической группы. Это может быть связано:

a) со сходством способа приготовления: сливуха 'картофельный суп' и 'каша из пшена и картофеля'. Отличительным признаком приготовления обоих блюд является сливание воды;

б) со сходством формы номинируемого блюда: колобышки 'пышки' и 'оладьи' (оба изделия имеют форму круга);

в) со сходством вкуса номинируемого кушанья: кислица 'каша из заваренной муки с добавлением различных ягод и фруктов' и 'щи с кислой капустой' (их объединяет кислый вкус);

г) с широким и размытым значением корня, который может отражать свойства различных блюд: дрочена 'кушанье из запеченной каши, молока и яиц', 'картофельные оладьи', 'яичница'.

Другим источником диалектной синонимии являются словообразовательные процессы. Большинство представленных лексем имеют общеславянские корни (варенуха, крошенка, мятка), являющиеся системными для русского национального языка. Активное функционирование исконных для исследуемой нами диалектной макросистемы корней обусловило образование новых слов с помощью аффиксов.

В тематической группе «Названия пищи» самым частотным способом образования является суффиксальный: гороховииа, грибник, солодуха и др. Зафиксированные синонимические соответствия являются именами существительными, которые могут образовываться от 1. существительных (караваеи $\leftarrow$ каравай); 2. прилагательных (грибник $\leftarrow$ грибной); 3. глаголов (крошенка $\leftarrow$ крошить). Среди суффиксов можно отметить следующие: $-y x$ (солодуха ‘свекольный суп', ‘блюдо из заваренной муки с добавлением 
свекольного сока'; затируха 'суп из затертой ржаной муки'; мятуха 'картофельное пюре'; глазуха 'яичница'), -ик- (ушник 'гречневый суп', 'гречневая каша' (от ушное); грибник 'грибной суп'), -'ак- (крутяк 'густая часть супа'; молошняк 'молочный суп'), -ок- (кулешок 'пшенный суп'; зварок 'компот'), -ищ(щербщuа 'уха'; кислища 'каша из заваренной муки с добавлением различных ягод и фруктов', ‘щи с кислой капустой').

Отметим, что выделяются ряды синонимических соответствий, которые состоят только из однокоренных слов, различия в словах обеспечиваются лишь аффиксами: кали'на - кали'нка - кали'нник 'каша из заваренной муки с добавлением различных ягод и фруктов (калины, яблок, вишен)'; тыл'квенник тылве'шник - тыквя'нка 'тыквенная каша'; варену'ха - зава'p - звар - зваро'к изва'р-изва'рчик-узва'р 'компот'.

Таким образом, наличие разнообразных блюд из определенного набора ингредиентов в воронежских говорах способствовало появлению богатства лексики, связанной с обозначением пищи. Выявленные синонимические соответствия отражают детализацию названий сходных явлений по каким-либо признакам, кажущимся важными носителям говора. Основными принципами номинации являются следующие: по способу приготовления, по основному продукту, по консистенции, по вкусу и по форме. Самым распространенным способом образования является суффиксальный, отмечается определенный набор суффиксов, которые участвуют в образовании слов в данной тематической группе. Проанализированный нами материал свидетельствует о большом количестве и активном функционировании названий пищи в воронежских говорах.

\section{Summary}

The article deals with synonymous correspondences in Voronezh food names. The paper presents the constructed synonymic series, describes the various principles of nomination, analyzes the word-forming processes. Therefore, a conclusion is made about the frequency of certain motivational signs, as well as about the features of the functioning of the identified synonymic correspondences. 
Синонимические соответствия в тематической группе «Названия пищи»

(на примере воронежских говоров)

\section{Литература}

Блинова, О.И. Введение в современную региональную лексикологию. Томск: Издательство Томского университета, 1975.

Даль, В.И. Толковый словарь живого великорусского языка. В 4 m. Москва: Русский язык, 1935.

Карасева, Т.В. Названия пищуи в воронежских говорах (этнолингвистический аспект). Диссертаџия канд. филол. наук. Воронеж, 2004.

Ковалев, Г.Ф. (ред.) Словарь воронежских говоров. Bыn. 1-3. Воронеж: Издательский дом ВГУ, 2004-2019-.

Филин, Ф.П., Сороколетов, Ф.П., Мызников, С.А. (ред.) Словарь русских народных говоров. Bыл. 1-49-. Москва-Ленинград: Наука, 1965-2016-.

Черных, П.Я. Историко-этимологический словарь современного русского языка. I том. Москва: Русский язык, 1999. 